\title{
Plant Succession and Plant Distribution in South Africa.
}

\author{
BY \\ J. W. BEWS, M.A., D.Sc., \\ Professor of Botany in the Natal University College.
}

\section{INTRODUCTION.}

$A^{N Y}$ study of plant distribution in any country must take into account A the interesting hypothesis of age and area, which has been fully illustrated by Dr. J. C. Willis in numerous recent papers (14-21). When his first papers on Ceylon appeared, I was engaged on a fairly detailed analysis of the extensive grassland flora and plant succession in South Africa (8), and a somewhat superficial application of the age and area hypothesis to the South African grasses seemed on the whole to confirm Willis's results for Ceylon. Endemic species of Gramineae in South Africa tend to have comparatively narrow ranges, while non-endemic species have usually wider ones. At the same time, even granting these facts, and the much more definite ones brought forward by Willis, to be true (as of course they undoubtedly are), and granting further the perfectly reasonable contention that the longer a species exists in any country the wider will be its distribution in that country, yet it appeared clear that in a country like South Africa, with its great variations in climatic conditions, the action of the age and area rule must be profoundly modified.

The south-western region in South Africa is distinguished by a winter rainfall and dry summers, and has a distinctive flora with a very large number of endemic species which range all over it (5). The eastern side of the sub-continent has summer rains, and a flora which differs very greatly from the south-western. Nevertheless, in the south-western region, even in the Cape Peninsula on the western side of it, there are small outliers of eastern forest in certain moister climatic situations. The species composing such forests are eastern species, and for the south-western region would rank as 'wides', yet they have a small range in the south-western region, and would be considered as rare, or rather rare according to Willis's scheme. In the same way numerous south-western species extend eastward along

[Annals of Botany, Vol. XXXIV. No. CXXXIV. April, 1920.] 
the mountain ranges to the Drakensberg (detailed lists have been given in some of my former papers ' $(1,3,4)$ ). As far as the eastern region is concerned they are 'wides', yet they have an extremely restricted range in the eastern region. It may be emphasized that these are not a few isolated exceptions, for the numbers are considerable.

Again, if we take Natal, we find that on the tropical coast-belt there are a large number of tropical species which have a wide range to the north through the tropics. Out of a total of about 1,500 species 545 are recorded also in the 'Flora of Tropical Africa', or 36.3 per cent. These extend north of the Tropic of Capricorn. Now practically all those 545 species have a very narrow range in Natal, being confined to the frostfree localities of the narrow coast-belt, yet they are all 'wides' as far as Natal or South Africa is concerned. If we attempt to deal with Natal as a whole on the same lines as those adopted by Willis for Ceylon the results obtained are utterly different. The reason of course is obvious. Natal is a country with very diverse climatic conditions. One set of 'wides' from the south-west have a restricted distribution along the mountains of Natal, another set of 'wides' from the tropics have a restricted distribution along the coast-belt of Natal.

This line of criticism has to a large extent been met by Willis, though, as he admits himself, it is unfortunate that he did not do so in his earlier papers. In his reply to criticism by Ridley (12) he states $(17$, p. 19I), 'I much regret that in my Ceylon papers I did not make sufficiently clear the various conditions that might modify the action of my age and area rule. Partly this was because I thought that many were obvious, and partly because I was thinking more of making the law itself clear.' He goes on later to give a list of such modifying causes as follows $(17$, p. 206) :

I. Chance (the operation of causes as yet not understood) ;

2. Action of man in opening up a country, cutting of forest, exploring, making fires, \&c., \&c. ;

3. Interposition of barriers, such as mountains, broad rivers, desert, arms of the sea, sudden changes of climate from one district to the next, and the like;

4. Geological changes, especially if involving change of climate;

5. Serious changes of climate ;

6. Natural selection;

7. Local adaptation;

8. Dying out of occasional old species ;

9. Arrival of a species at its climatic limit;

I0. Density of vegetation upon the ground at the time of arrival of a species ;

II. Presence or absence of mountain chains ; 
I2. Relative width of the union between the country of departure and that of arrival.

He states further: "Some of these causes probably come into action in almost every single case of any individual species, though upon large numbers and in the long run they cancel out. All might have been covered had I added to my tentative statement of the law the phrase "so long as conditions remain constant", or words to that effect."

The chief causes which apply to Natal are Nos. 3 and 9 as given above, but the numbers involved are so large that there can be no question of their cancelling out, nor does a phrase such as 'so long as conditions remain constant' cover everything. It is not a question of present conditions remaining constant so much as that the law of age and area applies only to regions where conditions are fairly uniform, as in Ceylon and New Zealand. It is only in his latest paper on 'The Flora of Stewart Island ' (21) that Willis expressly recognizes this, but it appears to me to be the fact which above all others requires emphasis. In the same paper (21, p. 23) Willis draws a distinction between ecological and taxonomic distribution, and states that it is to the latter that age and area refers. 'The two lines of work', he says, 'are really very distinct, and have comparatively little overlap. The plants are locally distributed, within the area which is assigned to them by the passage of time, in accordance with their reactions to the various ecological factors which are operative there. Ecology simply seems to make what it can, so to speak, of the floras with which it is provided by the mere action of phylogenetic descent and of time.'

Whether or not the two lines of work are as distinct as Willis believes, it seems clear that ecological principles must modify the action of the age and area rule, and the object of this paper is to see how far plant distribution in South Africa can be explained on purely ecological lines. Certain general principles are put forward which, so far as I am aware, have not been expressly stated before. The very fruitful concept of plant succession is entirely ignored by Willis, yet it throws light on many facts which otherwise would remain obscure.

\section{Widely Distributed Species in South Africa.}

The fact that the only general 'flora' of South Africa, the 'Flora Capensis', is still incomplete, and more than half the total number of families were dealt with in the first three volumes, which were published nearly sixty years ago, at a time when Natal, the Orange Free State, and the Transvaal were almost entirely unexplored, makes any systematic investigation into plant distribution in South Africa a matter of considerable difficulty. We have, however, two or three fairly complete check-lists, and for our present purpose it is sufficient to pick out the species that are common to Natal on the eastern side, and the Cape Peninsula on the 
extreme south-west. The list for Natal is that by Medley Wood (22), and that for the Cape Peninsula by Bolus and Wolley-Dod (10). The former contains a total of nearly 3,500 species, and the latter over 2,000. There are 320 species common to both (not including ferns). Our object is to see whether ecologically these widely distributed species have anything in common, and, if so, whether such features differ from those possessed by species with a more restricted range.

Of the 320 species, 60 , or 19 per cent., are ruderals, many of them introduced, and that probably at different points. At any rate, it has always been recognized that common weeds spread very rapidly. This is duc partly to man's interference with natural conditions, partly to the fact that ruderal species are all good colonizers, and are spread rapidly either by the abundance of their seed production or by efficient vegetative reproduction. The class as a whole is distinguished by belonging to early stages of successions, the initial stages chiefly of various subseres, if we use Clements's system of nomenclature (11). Ruderals are killed out by taller growing species in the later stages of the succession. Annual plants (Therophytes) are common among these ruderals, and the majority of such annuals are widespread in South Africa, though other classes of annual plants are not.

Another 65 out of the 320 species are aquatic or marsh plants. There are 26 species of Cyperaceae, common to the Cape Peninsula and Natal, 7 Juncaceae, including the Palmiet (Prionum palmita) which forms large consocies, 5 Naiadaceae, and many other isolated species, e. g. Nymphaea stellata, Gunnera perpensa, Epilobium hirsutum, Limosella aquatica, Utricularia livida, Typha capensis, Phragmites communis, Agrostis lachnantha, Diplachne fusca, Polypogon monspeliensis.

It has long been realized by ecologists that water and marsh plants tend to have a wide distribution, and that the floristic composition of marsh vegetation tends to vary but little, even in different climatic areas, or with increase of altitude, \&c. This fact was pointed out in detailed ecological papers dealing with the vegetation of Natal $(2,4)$. Water presents a relatively uniform environment everywhere, but it is also a relatively unstable one. Water and marsh plants belong to the initial stages of the hydrosere, so that this large class of widely distributed plants, like the ruderals, have this feature in common, they belong to early stages of the succession. These two classes absorb between them 125 species, or 39 per cent. of the 320 .

The remaining 195 species belong to the xerosere. Among them are included many Drakensberg species, e.g. Metalasia muricata, Stoebe cinerea, Erica cerinthoides, E. hispidula, species of Helichrysum, \&c., which, as already mentioned, represent outliers of the south-western flora on the eastern mountains (though a great many such Drakensberg species which are really south-western do not extend quite so far west as the Cape 
Peninsula, and are not included in the 320 ). . On the other hand, the eastern (Natal) trees and shrubs which occur in the Cape Peninsula are confined to the small forest areas on the slopes of Table Mountain, where the rainfall is greater, and the summer heat is tempered by the southeastern mist clouds.

A few species which are common to Natal and the Cape are chiefly sea-shore plants, and extend right round the coast, e.g. Cryptostemma niveum, Dimorphotheca fruticosa, Osteospermum moniliferum, Passerina filiformis, Mesembrianthemum edule, Chenolea diffusa, Cynanchum obtusifolium, Chironia baccifera, Olea capensis, Ehrharta erecta, E. calycina, Sporobolus pungens, Stenotaphrum glabrum, though several of them do extend slightly inland.

A careful examination of the whole 195 shows that, with the exception of one or two forest trees (Podocarpus latifolia, Ocotea bullata, Curtisea faginea), these also belong to early stages in the succession (the initial stages of the xerosere). Take the grasses for instance. No fewer than 43 species are common to the Cape and Natal. Of these, 18 are either ruderal or vlei (marsh) grasses, 4 are sea-shore species, and the remainder are all primitive colonizing types, even including the xerophytic varieties of Anthistiria imberbis, which are found in the Cape Peninsula. The species Sporobolus indicus, Eragrostis curvula, Aristida angustata, A.barbicollis, Andropogon hirtus, Cynodon dactylon are examples. Reference to my published work on 'The Grasses and Grasslands of South Africa' (8) will make clear how closely similar the grasslands of the whole western side of South Africa are to the initial stages of the succession in the eastern grassveld region. The chief pioneer genera which help to establish grassland in all the eastern areas are Aristida, Evagrostis, Sporobolus, and Cynodon. These same genera are dominant in the climax stages of the primitive semi-open grassveld of the drier areas towards the west, and extend through the Karroo and semi-desert formations as well.

The trees and shrubs which are common to the Cape Peninsula and Natal are also particularly interesting. Some of them, e. g. Ilex mitis, Myrica conifera, are pioneers in the hydrosere, but the majority are light-demanding, deep-rooted, xerophytic species which in Natal grow outside the close forest, and act as pioneers in the xerosere; preparing the way for the more mesophytic, more ombrophilous kinds. I have described in detail elsewhere $(6,7)$ how Acacia horrida $(A$. karroo) is the most important pioneer in the extensively developed thornveld. It invades grassiand, and a great many species which cannot themselves act as pioneers, grow up underneath it and finally often overtop it and kill it. It is one of the most widely distributed species in South Africa. Another pioneer species, Myrsine africana, which is very important in the establish- 
ment of forest in the Drakensberg (4), extends from Natal to the Cape. The most important pioneer trees and shrubs in Natal are included in the following list, which very nearly exhausts all those common to the Cape Peninsula and Natal: Rhus villosa, R. pyroides, R. lucida, Cunonia capensis, Olinia cymosa, Sideroxylon inerme, Royena lucida, Celastrus buxifolius, C. acuminatus, Myrsine africana, Olea vermesa, Celtis rhamnifolia, Kiggelaria africana, Scolopia mundii, Grewia occidentalis, Noltea africana, Cliffortia strobilifera, Psoralea pinnata, Plectronia ventosa, Halleria lucida. Myrsine melanophleos is a forest tree which, though it can withstand shade, also often acts as a pioneer, being rather widely adaptable.

There are a few light-demanding climbers which extend from the Cape to Natal, e.g. Clematis brachiata, Scutia indica, Vitis capensis, Asparagus africana, $A$. aethiopicus, $A$. medioloides; and a few parasitic species have the same wide distribution, e.g. Cassytha capensis, Harveya corcinca, $H$. purpurea, H. squamosa, H. bolusii, Melasma sessiliflorum, Thesium spicatum, Viscum obscurum. The wide distribution of these latter is not easy to explain either on ecological lines or by the age and area rule, for presumably they are younger than their hosts.

It is interesting to find that the species which commonly take possession after fire, e. g. Rubus pinnatus, Polygala myrtifolia, $P$. virgata, are again widespread types. They represent once more the initial stages of subseres.

The result of this comparison of widespread species in South Africa appears to be that while they are seen to belong to widely different growth forms, and to show no possible phylogenetic relationship, yet with very few exceptions they agree in belonging to early stages of the plant succession. They act as pioneers which colonize either waste land or cultivated fields, or burnt-out forest, or they invade lakes and pools and vleis, or they colonize sand-dunes and open sea-shore habitats, or they belong to early stages of the main xerosere, and often play an important part in the establishing of grassland or forest plant communities. The results, then, appear to justify the putting forward of the following hypothesis :

Species with a wide distribution are usually found in an early stage of the plant succession.

The rule probably only applies to countries where there are great variations in climatic conditions, such as is the case in South Africa, where the climax types in drier parts so often represent the initial stages of succession in moister regions. This result is not to be considered as in any way contradictory to the age and area law already discussed. It is rather an ecological amplification of that law, and it is bound up with other principles of plant succession.

Succession as a rule proceeds from extremes, where there is either too much or too little water, towards the mesophytic, and the highest stage of 
development is forest. If now we suppose that two separate groups of species were produced by mutation at the same time, one inside the forest, the other outside, but, as might easily happen, very near to each other geographically, the former would only spread up to the limits of the forest climatic area. In South Africa at the present time such areas are comparatively limited in extent, and are separated by drier areas, which any forest species has difficulty in crossing. The species produced outside the forest are of necessity of a more xerophytic light-demanding type, and are able to spread over all the drier areas, but cannot invade the forest. They can, however, extend into regions, such as all the dry western parts of South Africa, where the climatic conditions are such that no forest development is possible. In course of time they come to have a much wider distribution than the species which we have postulated to be of the same age.

It may be well to point out that it is not necessary to take a large area like the whole of South Africa to find an application for the above principle. Even in smaller areas, such as Natal, it applies equally well. The early stages of succession contain the same species on the coast-belt, in the midlands, and in the mountain regions, but later stages differ much more in the different parts. Grassland is far more uniform over Natal than the scrub and forest which invade it. The widespread species over any area, large or small, belong to early stages of the succession. It must be remembered that in Natal climatic variations are great, even in small areas, the valley climates differing from those of the surrounding hills. The climax type in the former is dry thorny scrub, but that of the latter mesophytic forest. Nevertheless the differences in the two types of grassland which precede (the low veld in the case of thorny scrub and the high veld in the case of forest) are only slight. The same grassland species range over both $(2,5)$.

Though it appears to be true (for South Africa at least) that widespread species appear early in the succession, it does not of course follow that all species which appear early in the succession are widespread. Many pioneer species, e.g. numerous species of Crassula, which colonize rocks, are, so far as is known, not particularly widespread. Such species have not reached the limits of their climatic areas, and, if we apply the age and area law to them, may be ranked as relatively young; but it should further be remembered that pioneer species are readily killed out by species which appear later in the succession, and for strict pioneers any close relatively stable plant community is itself a barrier. Most species of Crassula cannot invade grassland, much less forest, and they may find it difficult to migrate from one rocky region to another across great stretches of grassland. 


\section{Species with Restricted Distribution in South Afric.}

It is interesting to inquire how far the converse of the above rule (namely, that species with a restricted distribution or narrow range belong to late stages of the succession) does hold for South Africa. It is clear, from what has already been said, that it does not hold altogether, for pioneer species may have a restricted distribution. Nevertheless there are certain large classes of rare or relatively rare species (using rare in the sense used by Willis, of being restricted to a fairly small area) which, it will be shown, belong of necessity to climax or subclimax stages of succession. In a paper (now in the press) (9) dealing with the plant ecology of the Natal coast-belt, I have analysed the floristic composition of the vegetation, and have pointed out that as the succession advances in the various seres (hydrosere, psammosere, xerosere, halosere), the vegetation becomes more and more tropical, 84 per cent. of the genera and $3^{6}$ per cent. of the 1,500 coast-belt species extend through the tropics, and there are in addition a large number of endemic species. All. these tropical and endemic coastbelt species do not spread outside the frost-free localities on the Natal coast-belt, and as far as South Africa is concerned they are rather rare. Almost all of them appear late in the succession in scrub or forest. The marsh plants and even the grassveld species, with one or two exceptions, are all the same as occur in the midlands of Natal and other colder parts of South Africa. Among the grasses it is particularly interesting to compare the various species in the coast grassveld, which, with the exception of three or four, are the same as over the whole eastern grassveld region, with the numerous tropical or endemic species of Panicum, \&c., which are abundant round the moist fringe of the coast forest, but do not enter into grassveld. The coast scrub and forest have been analysed in considerable detail, and over 700 species have been listed and symbols of relative frequency given. The great majority of them do not occur elsewhere in South Africa.

There are over 60 species of Acanthaceae alone, and the family is not even represented at the Cape. The numerous climbing species of Asclepiadaceae are quite distinct from the more widely distributed grassveld and western species of the same family. Tropical members of the families Anonaceae, Capparidaceae, Bixineae, Urticaceae, Euphorbiaceae, Cucurbitaceae, Convolvulaceae, Amarantaceae, Verbenaceae, Leguminosae, \&c., are nearly all confined to this subclimax or climax type (scrub and forest) on the Natal coast-belt. Whether 'wides' or endemics, they are all restricted in their distribution in South Africa.

Elsewhere on the eastern side it is also true that a great many species with restricted distribution are forest species. Two endemics which are often completely dominant in forests (Podocarpus falcata and Xymalos 
monospora) are among the number. A very large proportion of the total number of species, however, are geophytic herbaceous forms, which are scattered among the grasses of the grassveld, and next to nothing is really known about their distribution. Many of them are certainly widely distributed, e. g. those named in my work already referred to, but these also obey the general rule given above, for they are vernal plants and increase when the plant succession is sent back by grass burning or overstocking, i. e. they belong to an early stage of the succession.

Over the whole dry interior, the Karroo, the sand veld, and the western regions, the vegetation is mostly of a semi-open primitive type, and, though practically the whole of these great areas is insufficiently explored to enable any exact information to be given as to the distribution of the different species, yet many of them are at least known to be widespread, though at the same time they may be endemic.

The south-western or Cape region, where the climax stage of the plant succession, except in a few forest areas, is Macchia, is of peculiar interest in many ways. The number of endemic species is extraordinarily high. Some of them range all over the region, others are very rare indeed, at least as far as is known, but again much more information is necessary before any very definite statement can be made. The climatic conditions over the area are on the whole fairly uniform, and interesting results should be obtainable by applying the age and area law to this region.

So far I have confined my attention to South Africa, in this attempt to throw some further light on the question of plant distribution by applying ecological, and particularly successional, principles. At present I do not propose to enter into further details with regard to South Africa, or to attempt to apply the same methods to other countries, though there is much information scattered through ecological literature which has a bearing on the question. Thus Smith, in his Presidential Address to the British Ecological Society (13), dealt, inter alia, with the reasons why some grasses are widely distributed in Britain. It is interesting to find that he laid stress on their possessing high powers of surviving critical periods, especially winter and drought, but certain colonizers he notes as being restricted in distribution. Of course it is not claimed, even for South Africa, that pioneer species are necessarily widespread, though widespread species usually appear early in the succession. The climate of Britain, too, is very uniform as compared with that of any part of South Africa, and where the ecological sorting out depends more on edaphic than on climatic conditions, it is uncertain whether my rule will apply. The important thing, however, seems to be that any widespread species must have the environmental conditions which suit it also widespread. Early species in the succession, which have to be adapted chiefly to the inorganic environmental factors, are more likely to find those conditions to which they are 
suited widespread over any area, than those species which belong to complex climax plant communities, where the surrounding vegetation is the most important factor for any particular species. This is especially true for the very mixed forests of Natal or any other subtropical or tropical region.

Willis, in his various papers, seldom refers to the ecological side of the question, but one or two of his statements are significant. Thus, in his Ceylon paper, he says (15, p. I3), ' The number and proportion of endemics are far greater in the wet south-western zone, i. e. in the broken hilly country of Ceylon, than in the flat and uniform dry country which surrounds it to the north-east and south-east', and of course he has already shown that endemics are relatively restricted in their distribution. The fact that they belong to the moister parts agrees very well with what happens in South Africa, but in the moister parts the highest stages of the plant succession are able to develop, and it is to these complex plant communities that the endemics and species with restricted distribution belong.

Again, in his first New Zealand paper (16), Willis's figures show that in the Cyperaceae, a family which is fairly uniform in its ecological behaviour, since most of its members belong to early stages of the (hydrosere) plant succession, both endemics and wides are widely distributed. Willis explains this by stating that the family is very old in New Zealand, but it can be equally well explained by the theory outlined above.

\section{Summary.}

I. Willis's 'age and area' law is discussed, and in general accepted, but it is pointed out that it can only apply to regions where conditions are fairly uniform, and in South Africa, where climatic variations are extreme, its operation is greatly modified.

2. Species (320 in number) which are widely distributed over South. Africa are compared, and it is found that such species usually are found in an early stage of the plant succession. They include many ruderal species which colonize waste land, \&c., many aquatic and marsh plants which belong to early stages of the hydrosere, and the remainder are nearly all xerophytic, light-demanding species, which belong to early stages of the xerosere, and are often important pioneers in the establishing of grassland, scrub, or forest plant communities.

3. On the other hand, some strictly pioneer species are not widely distributed. In many cases this is probably due to the more stable plant communities acting as barriers and retarding the spread of the pioneers.

4. Certain large classes of species with a restricted distribution in South Africa are shown to belong to climax plant communities such as the coast-belt forest of Natal, as well as other forests. Reference is made to work recently completed (9) in which it is shown that in a subtropical 
region such as the Natal coast-belt, as succession advances, the vegetation becomes more and more tropical, so that, while all the earlier stages of the succession in this area are widespread over the rest of Natal or farther, there are some 700 tropical or endemic species which are more or less confined to the climax or subclimax forest or scrub of the Natal coast-belt, and are thus very restricted in their distribution, so far as South Africa is concerned.

\section{BIBLIOGRAPHY.}

1. Bews, J. W.: The Vegetation of Natal. Ann. of Natal Mus., vol. ii, Part 3, I9I 2, p. 253.

2. - An Ecological Survey of the Midiands of Natal, \&c. Ann. of Natal Mus., vol. ii, Part 4, I9I3, p. 485 .

3. - Growth Forms of Natal Plants. Trans. Roy. Soc. of S. Africa, 1916, p. $60_{5}$.

4. $:$ The Plant Ecology of the Drakensberg Range. Ann. of Natal Mus., vol. iii, Part 3, I917, p. 5 II.

5. - An Account of the Chief Types of Vegetation in South Africa, with Notes on the Plant Succession. Journ. of Ecology, vol. iv, 3 and 4, I9 I6, p. I 29.

6. : The Plant Succession in the Thorn Veld. S.A. Journ. of Science, Nov., I9I7, p. I 53 .

7. - South African Phytogeography. S.A. Geog. Journ., I9I7, p. II.

8. 9.

10. Bolus, H., and Wolley-Dod, A. H. : A List of the Flowering Plants and Ferns of the Cape Peninsula. Trans. of S.A. Phil. Soc., 1903, p. 207.

11. Clements, F. E. : Plant Succession. Washington, igi6.

12. Ridley, H. N. : On Endemism and the Mutation Theory. Ann. of Bot., vol. xxx, 1916, p. 55 I.

13. Smith, W. G.: President's Address (to the British Ecological Society). Journ. of Ecology, vol. vii, I and 2, I919, p. I Io.

14. Willis, J. C.: The Endemic Flora of Ceylon, \&c. Phil. Trans., B., vol. ecvi, I9I5, p. 307.

15. - The Evolution of Species in Ceylon, \&c. Ann. of Bot., vol. xxx, 19i6, p. I.

16. : The Distribution of Species in New Zealand. Ann. of Bot., vol. xxx, r916, p. 437 .

17. $:$ The Relative Age of Endemic Species, \&c. Ann. of Bot, vol.xxxi, I9I7, p. I89.

18. : The Distribution of the Plants of the Outlying Islands of New Zealand. Ann. of Bot., vol. $x x x i, 19$ I 7, p. 327.

19. : Further Evidence for Age and Area, \&c. Ann. of Bot., vol. xxxi, I9I7, p. 335.

20. $:$ The Sources and Distribution of the New Zealand Flora, \&c. Ann. of Bot., vol. xxxii, r918, p. 339 .

21. $:$ The Flora of Stewart Island. Ann. of Bot., vol. xxxiii, 1919, p. 23.

22. Wood, J. Medley : Revised List of the Flora of Natal. Trans. of S.A. Phil. Soc., I908, p. I 2 I. 


\section{$2 \mathrm{BHL}$ Biodiversity Heritage Library}

Bews, J. W. 1920. "Plant succession and plant distribution in South Africa." Annals of botany 34, 287-297. https://doi.org/10.1093/aob/os-34.2.287.

View This Item Online: https://www.biodiversitylibrary.org/item/236972

DOI: https://doi.org/10.1093/aob/os-34.2.287

Permalink: https://www.biodiversitylibrary.org/partpdf/320288

\section{Holding Institution}

Smithsonian Libraries

\section{Sponsored by}

Biodiversity Heritage Library

\section{Copyright \& Reuse}

Copyright Status: Not in copyright. The BHL knows of no copyright restrictions on this item.

This document was created from content at the Biodiversity Heritage Library, the world's largest open access digital library for biodiversity literature and archives. Visit BHL at https://www.biodiversitylibrary.org. 